\title{
CHANGES IN PERIPHERAL PLASMA PROGESTERONE THROUGHOUT THE OESTROUS CYCLE OF THE PONY MARE
}

\author{
D. C. SHARP* AND D. L. BLACK \\ Laboratory for Reproductive Physiology, \\ Department of Veterinary and Animal Sciences, \\ University of Massachusetts, Amherst, Massachusetts 01002, U.S.A.
}

(Received 13th December 1972)

Progesterone patterns in the peripheral plasma of mares have recently been reported by Smith, Bassett \& Williams (1970), Stabenfeldt, Hughes \& Evans (1971), and by Plotka, Witherspoon \& Foley (1972). In the research reported here, progesterone levels were measured in the peripheral circulation of pony mares.

Mature pony mares of mixed breeding were checked daily for oestrus by teasing with a vigorous stallion. Blood samples were collected daily from indwelling jugular vein cannulae. After extraction of progesterone from 1- or 2-ml plasma samples with diethyl ether, the ether extract was partially concentrated by evaporation under nitrogen, and transferred to pre-coated thinlayer chromatography plates (Machery-Nagel). Progesterone was separated from other ether-soluble plasma components by one-dimensional chromatography in ether:benzene $(2: 1)$. Scraping the thin-layer plates with a razor blade to remove progesterone yielded a tight cylinder of silica gel small enough to be placed into the barrel of a Pasteur pipette, the tip of which was plugged with polyester filter fibre. Progesterone was eluted from the silica gel by passing $3.5 \mathrm{ml}$ methanol through the pipette. This method, in essence, acted as a second chromatography. The amount of progesterone present was determined by competitive protein-binding assay as reported by Neill, Johansson, Datta \& Knobil (1967). Human blood plasma was used as the source of corticotrophinbinding globulin (CBG).

In the absence of authentic progesterone, $82.5 \%$ tritiated corticosterone was bound in a $0.5 \%$ solution of the CBG plasma. The working range of the standard curve was from $0.22 \mathrm{ng}$ to $3 \mathrm{ng}$ progesterone. Aliquots of water (1 or $2 \mathrm{ml}$ ) that were extracted and chromatographed with samples yielded assay levels of $0.35 \pm 0.1 \mathrm{ng} / \mathrm{ml}$. The accuracy of the method was determined by measurement of $15 \mathrm{ng}$ progesterone added to stallion plasma. The average amount of progesterone measured in this preparation was $14 \cdot 8 \pm 0 \cdot 8 \mathrm{ng} / \mathrm{ml}$. Murphy $(1964,1967)$ reported that the specificity of the competitive proteinbinding assay depends largely on the limited number of steroids which com-

* Present address : Department of Veterinary Science, University of Wisconsin, Madison, Wisconsin 53706, U.S.A. 
pete with corticosterone for sites on the CBG molecule and on the method of extraction. In this study, diethyl ether was used for progesterone extraction to reduce a problem with the solvent blanks that existed with petroleum ether. Since diethyl ether, unlike petroleum ether, does not extract steroids differentially (Johansson, 1969), the thin-layer chromatography step was considered necessary (Thorburn, Bassett \& Smith, 1969).

The average duration of the oestrous cycle was $22 \cdot 6 \pm 1.5$ days. The average durations of oestrus and dioestrus were $6 \cdot 6 \pm 1 \cdot 2$ days and $16 \cdot 0 \pm 1 \cdot 3$ days, respectively. The progesterone levels reported here agree well with other reports (Short, 1959; Smith et al., 1970; Stabenfeldt et al., 1971; Plotka, Witherspoon \& Goetsch, 1971) (Table 1). During oestrus, progesterone concentrations were low (average concentration at oestrus was $0.58 \mathrm{ng} / \mathrm{ml}$ ) and often below the detection limit $(0.22 \mathrm{ng})$ of the assay. Typically, an abrupt increase in peripheral progesterone occurred after cessation of heat. The first time that progesterone rose $100 \%$ over the previous day was 1.1 days after the end of heat. Plotka et al. (1972) reported a major increase in progesterone

Table 1. Progesterone values in the mare

\begin{tabular}{l|c|c}
\hline \multicolumn{1}{c|}{ Investigator } & $\begin{array}{c}\text { Follicular } \\
\text { phase } \\
(\mathrm{ng} / \mathrm{ml})\end{array}$ & $\begin{array}{c}\text { Luteal } \\
\text { peak } \\
(\mathrm{ng} / \mathrm{ml})\end{array}$ \\
\hline Short (1959) & - & $8 \cdot 0^{*}$ \\
Smith et al. (1970) & $0.64 \pm 0.2$ & $7.7 \pm 3.8$ \\
Stabenfeldt et al. $(1971)$ & 0.65 & 10.0 \\
Plotka et al. (1971) & $0.61 \pm 0.4$ & $9 \cdot 4 \pm 5 \cdot 0$ \\
Present report & $0.58 \pm 0.2$ & $10.9 \pm 1.4$ \\
\hline
\end{tabular}

* Mid-luteal only.

$36 \mathrm{hr}$ after ovulation. Text-figure 1 is a composite of progesterone values obtained during twelve oestrous cycles in nine mares; the progesterone values are shown in reference to the first day of dioestrus. Because of the small size of the animals, rectal palpation of the ovaries was impossible; the exact timing of ovulation, therefore, was not known. Ovulation, however, usually occurs 24 to $48 \mathrm{hr}$ before the end of oestrus in the mare (Nishikawa, 1959; Asdell, 1964; Witherspoon \& Talbot, 1970). The time taken for progesterone to reach a dioestrous peak was quite variable from animal to animal, although 7 days of dioestrus was the average time required. Smith et al. (1970) reported that the progesterone concentration decreased slightly after reaching the dioestrous peak, then seemed to increase again to a second peak. Although not evident from Text-fig. 1, this tendency was also seen in a majority of mares in this study (Text-fig. 2). The possible physiological significance of the second peak cannot be determined from this study.

The changes in peripheral progesterone concentrations throughout the oestrous cycle of the mare correlate well with oestrous activity. Oestrous behaviour was generally not seen in mares until the peripheral progesterone had dropped to a level of $1 \mathrm{ng} / \mathrm{ml}$ or lower. This is in agreement with Plotka et al. 


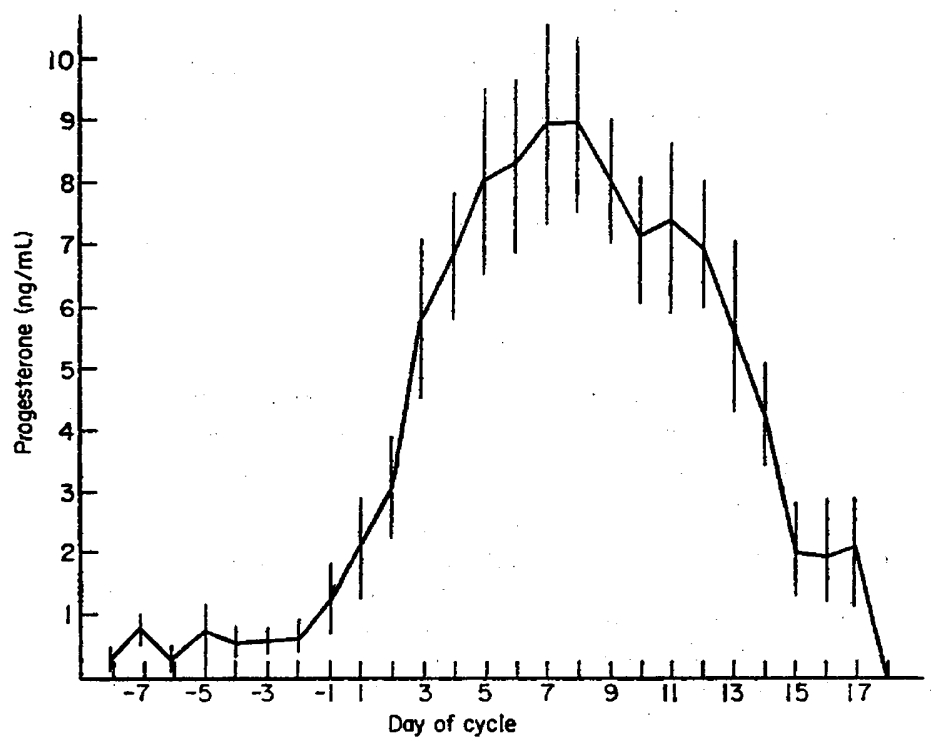

TexT-Frg. 1. Average progesterone levels in blood plasma from pony mares (twelve oestrous cycles, nine mares). The vertical bars represent the standard error of the mean. The days of oestrus are shown with minus signs; the first day of dioestrus is Day 1.

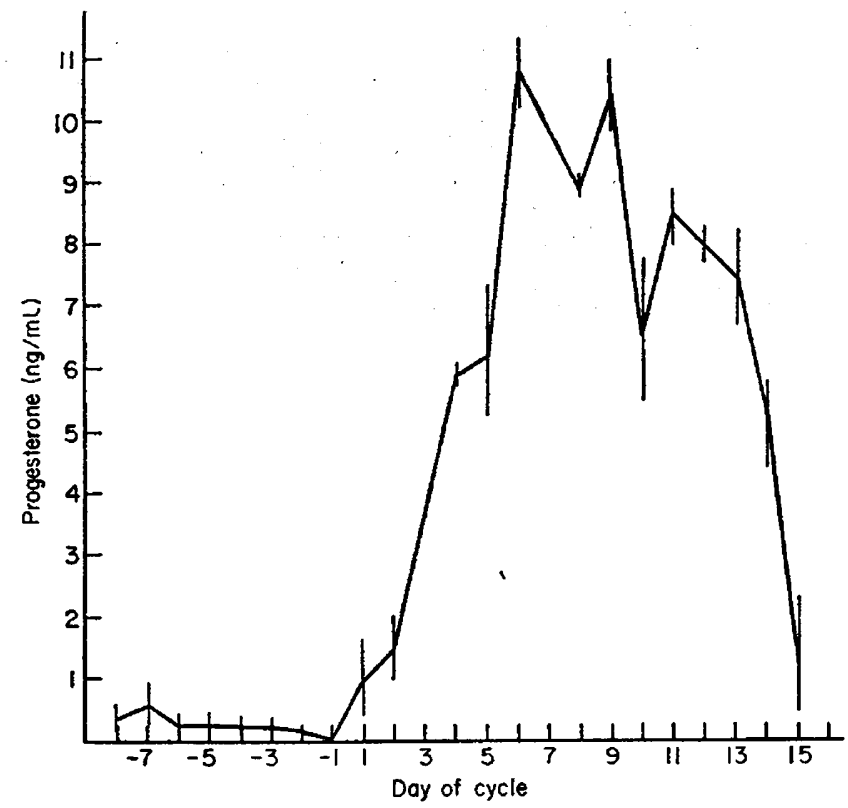

TExT-Fio. 2. Average plasma progesterone levels during an oestrus cycle in an individual mare. The vertical bars represent the standard error of the mean from triplicate determinations. 
(1972). Peripheral progesterone concentration and corpus luteum function are related in other species (Plotka, Erb, Callahan \& Gomes, 1967) and it seems reasonable to assume that daily measurements of plasma progesterone can also be an effective method for determining cyclic corpus luteum function in the mare.

This work was supported in part by the Grayson Foundation, Inc., Lexington, Kentucky.

\section{REFERENCES}

Aspeli, S. A. (1964) Patterns of mammalian reproduction, p. 516. Cornell University Press.

Johansson, E. D. B. (1969) Progesterone levels in peripheral plasma during the luteal phase of normal human menstrual cycle measured by a rapid competitive protein binding technique. Acta endocr., Copenh. 61, 592.

MURPHy, B. E. P. (1964) Application of the property of protein-binding to the assay of minute quantities of hormones and other substances. Nature, Lond. 201, 679.

Murphy, B. E. P. (1967) Some studies of the protein-binding of steroids and their application to the routine micro and ultra-micro measurement of various steroids in body fluids by competitive protein binding. F. clin. Endocr. Metab. 27, 973.

Neill, J. D., Johansson, E. D. B., Datta, J. K. \& Knobir, E. (1967) Patterns of circulating progesterone concentrations during the fertile menstrual cycle and in the remainder of gestation in the rhesus monkey. Endocrinology, 84, 45.

NrsHIKAWA, Y. (1959) Studies on reproduction in horses. Singularity and artificial control in reproductive phenomena. Japan Racing Association. XII, Tokyo.

Plotka, E. D., ERb, R. E., Gallahan, C. J. \& Gomes, W. R. (1967) Levels of progesterone in peripheral blood plasma during the estrous cycle of the bovine. F. Dairy Sci. 50, 1158.

PlotkA, E. D., Witherspoon, D. M. \& Foley, C. W. (1972) Luteal function in the mare as reflected by progesterone concentrations in peripheral bood plasma. Am. J. vet. Res. 33, 917.

Plotka, E. D., Witherspoon, D. M. \& Goetsch, D. D. (1971) Peripheral plasma progesterone levels during the estrous cycle of the mare. Fedn Proc. Fedn Am. Socs exp. Biol. 30, 419.

SHORT, R. V. (1959) Progesterone in blood. IV. Progesterone in the blood of mares. F. Endocr. 19, 207.

Smith, I. D., BassetT, J. M. \& Williams, T. (1970) Progesterone concentrations in the peripheral plasma of the mare during the estrous cycle. 7 . Endocr. 47, 523.

Stabedfeldt, G. H., Hughes, J. P. \& Evans, J. W. (1971) Studies on the estrous cycle of the mare. Fedn Proc. Fedn Am. Socs exp. Biol. 30, 419.

Thorburn, G. D., BAsSeTt, J. M. \& SMrth, I. D. (1969) Progesterone concentrations in the peripheral plasma of the sheep during the oestrous cycle. 7 . Endocr. 45, 459.

Witherspoon, D. M. \& TAlbot, R. B. (1970) Nocturnal ovulation in the equine animal. Vet. Rec. $87,302$. 